\title{
Community Water Conservation and Village Institutions: A Model of Water Resource Sustainability
}

\author{
Suryatri Darmiatun ${ }^{1, *}$ \\ ${ }^{I}$ Vocational Education Management, BBPPMPV BOE Malang, 65102, Indonesia \\ *Corresponding author. Email: atuntasrial@ gmail.com
}

\begin{abstract}
The source of drinking water for most of the villagers in Malang Regency, East Java comes from springs. 60 springs in Malang Regency; 3 points for surface water, 41 springs and 16 points for deep wells; experience shrinkage. Water protection / conservation by government and non-government is a prerequisite for the sustainability of access to drinking water for rural communities. Research has not yet been carried out on a water resource sustainability model, based on water conservation by villagers and village institutions. The research aims to: determine the magnitude of the social and institutional effects of the village on the sustainability of water resources, and to formulate a sustainable model of water resources based on community and village institutions. Data collection methods are surveys, interviews, and document studies. The research data were analyzed using WarpPLS. Social factors $\left(f^{2}=0.092\right)$ and community economy $\left(f^{2}=\right.$ 0.024), have a direct effect on the performance of village institutions, but have no effect on the implementation of water conservation. The sustainability of water resources in rural areas is directly affected by the implementation of water conservation $\left(\mathrm{f}^{2}=0.250\right)$. The implementation of water conservation mediates the effect of community-village institution collaboration $\left(f^{2}=0.134\right)$ and the performance of village institutions $\left(f^{2}=0.189\right)$ on the sustainability of water resources.
\end{abstract}

Keywords: Conservation, Water Resources, Village, Structural Model.

\section{INTRODUCTION}

The shrinkage of water discharge occurred at 60 springs; 3 surface water points, 41 springs and 16 deep wells; in Malang Regency. The Malang Regency area is crossed by 10 large rivers, such as the Brantas River which has 9 tributaries and has 27 branches or has fins. Depreciation of various springs originating from large rivers is a warning. Shrinkage gets worse when the dry season enters [1] [2]. Conservation of water resources by the community together with village institutions has obstacles to continue. These obstacles are related to the principles of decision making, the right to organize, and improvement / development. The government has not sufficiently encouraged sustainable independent governance in village communities [3]. The problems that need to be studied are what are the actual social and village institutional effects on water conservation, and how is the formulation of a community-based water resources sustainability model and village institutions.

The results of previous research stated that the village community had carried out physical and non-physical conservation of water resources through cultural and non- cultural activities (agreement). Conservation activities are still focused on utilization, not on the protection, improvement and guarantee of the carrying capacity of water resources. Indonesia's water resources management policies, regulations and controls have implementation constraints. These obstacles are in the form of neglect of enforcement of regulations and empowerment of local resources and the capacity of local institutions. Togetherness of government and society is needed in carrying out conservation of water resources in a sustainable manner [4]. The research methods used are the SWAT model, remote sensing, RAPFISH, case study, and descriptive method [3] [4]. These studies have not determined the main factors and determined the most effective intervention path for the sustainability of water resources. Therefore, the concept of research carried out is structural modeling of sustainable water resources conservation. The modeling is based on an analysis of the strength of the roles and patterns of the main relationships between the community and village institutions in implementing water conservation. 
The research aims to: determine the magnitude of the social and institutional effects of the village on the sustainability of water resources, and to formulate a sustainable model of water resources based on community and village institutions. Primary data were obtained through surveys and interviews. Secondary data were obtained through document study. Survey data were analyzed using the WarpPLS program. Interview data and document study are required for in-depth study of the results of survey data analysis.

\section{METHOD}

The research data were obtained by survey methods, interviews and document study. Research respondents were $10 \%$ (ten percent) of drinking water users who use open water sources (springs and rivers) in 6 (six) villages of Poncokusumo District, Malang Regency, East Java, Indonesia. Data were analyzed using SEM-PLS (Structural Equation Model-Partial Least Square) with the WarpPLS program [5]. The research variables are social ( 3 indicators), economy ( 3 indicators), institutional (8 indicators), partnership (5 indicators), water conservation (4 indicators), and sustainability of water resources (5 indicators). Social and economic variables are exogenous variables. Institutional variables, partnership, and water conservation act as mediating variables.

Note: $\mathrm{S}=$ Social; $\mathrm{E}=$ Economy $; \mathrm{I}=$ Institutional; $\mathrm{P}=$ Partnership; $\mathrm{WC}=$ Water Conservation; SWR = Sustainability of Water Resources.

\section{RESULT AND DISCUSSION}

\subsection{Presenting the Results}

From 2000 to 2018 there was a change in the percentage of land vegetation density in Poncokusumo District. In 2000, land cover was dominated by vegetation density with a canopy percentage between 80 percent and 90 percent. In 2018, there was an increase in land cover by vegetation density with the percentage of the canopy ranging from 0 percent to 60 percent. There has been a change in land use, previously for fields and forests (in 2000) to open / shrublands, settlements, rice fields and moor (in 2018).

Community income relies mainly on agriculture, as indicated by farmers as much as $61.18 \% .59 .30 \%$ of the community has completed primary school level education. $87.48 \%$ of the people have an income below the Malang Regency Minimum Wage in 2019 (Table 1).

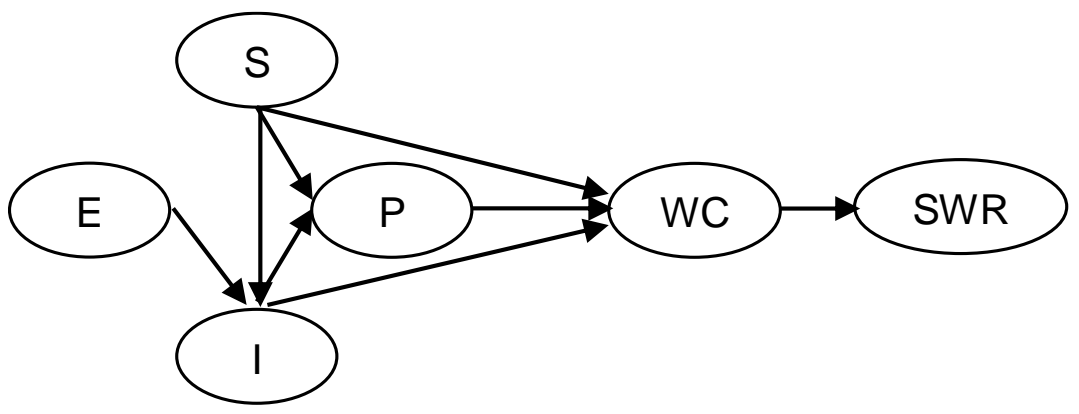

Figure 1 Structural Model of Water Resources Sustainability.

Table 1. Research Empirical Data

\begin{tabular}{|c|c|c|c|c|c|c|c|c|c|c|c|c|}
\hline \multicolumn{5}{|c|}{ Job (\%) } & \multicolumn{4}{|c|}{ Education (\%) } & \multicolumn{4}{|c|}{ Income $(\%)$} \\
\hline$\dot{\dot{z}}$ & 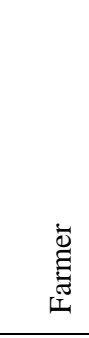 & 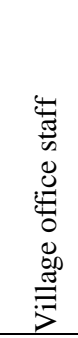 & 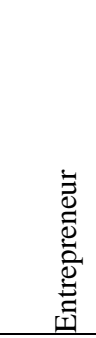 & 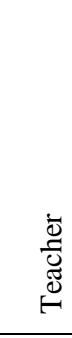 & 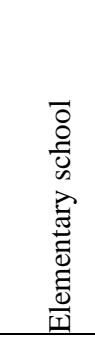 & $\begin{array}{l}\overline{8} \\
\overline{0} \\
0 \\
\dot{0} \\
. \\
\Xi\end{array}$ & $\begin{array}{l}\overline{8} \\
\overline{0} \\
\overline{0} \\
\overline{0} \\
\overline{000} \\
\overline{1}\end{array}$ & 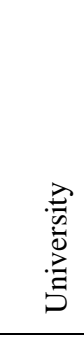 & $\begin{array}{l}8 \\
8 \\
8 \\
\infty \\
i \\
i\end{array}$ & $\begin{array}{l}8 \\
8 \\
8 \\
8 \\
n \\
\hat{n} \\
x \\
v \\
v 1 \\
8 \\
8 \\
8 \\
8 \\
\infty \\
i\end{array}$ & 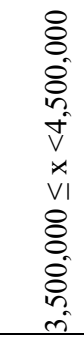 & $\begin{array}{l}8 \\
8 \\
8 \\
8 \\
\stackrel{n}{n} \\
+ \\
\wedge 1\end{array}$ \\
\hline 9.54 & 61.18 & 3.78 & 23.04 & 2.48 & 59.30 & 21.00 & 15.15 & 4.55 & 87.48 & 6.81 & 3.41 & 2.29 \\
\hline
\end{tabular}

Measurement model analysis shows that all variable indicators are valid and can be studied further in structural model analysis. The strongest indicators of each variable are: community honesty, willingness to contribute, PSDM, training and mentoring, local regulations, and environmental health. Table 2 shown Categories and Loading Factors Empirical Data. 
Table 2. Categories and Loading Factors Empirical Data

\begin{tabular}{|c|c|c|c|}
\hline Symbol & Name & Category & Loading factor \\
\hline \multirow{3}{*}{ Social } & Trust & Good & 0.706 \\
\hline & Honesty & Good & 0843 \\
\hline & Obedience & Good & 0.802 \\
\hline \multirow[t]{3}{*}{ Economy } & Willingness & Good & 0.361 \\
\hline & Ability & Good & 0.772 \\
\hline & Facility costs & Good & 0.683 \\
\hline \multirow[t]{8}{*}{ Institutional } & Ability details & Enough & 0.610 \\
\hline & PSDM & Less & 0.783 \\
\hline & Planning & Enough & 0.731 \\
\hline & Administration & Good & 0.631 \\
\hline & Coaching & Enough & 0.719 \\
\hline & Information Center & Less & 0.463 \\
\hline & Obedience & Good & 0.701 \\
\hline & Enforcement of regulations & Enough & 0.673 \\
\hline \multirow[t]{5}{*}{ Partnership } & Training and mentoring & Enough & 0.647 \\
\hline & Participation & Enough & 0.568 \\
\hline & Ease of obtaining information & Enough & 0.547 \\
\hline & Accompaniment & Enough & 0.641 \\
\hline & Management & Enough & 0.566 \\
\hline \multirow[t]{4}{*}{ Water conservation } & Government regulations & Good & 0.647 \\
\hline & Local regulations & Enough & 0.737 \\
\hline & Land & Enough & 0.640 \\
\hline & Sanitation & Good & 0.602 \\
\hline \multirow[t]{5}{*}{ Sustainability of water resources } & Water quantity & Enough & 0.497 \\
\hline & Water quality & Good & 0.601 \\
\hline & Greening & Enough & 0.701 \\
\hline & Health & Enough & 0.702 \\
\hline & Togetherness & Enough & 0.688 \\
\hline
\end{tabular}

Structural model analysis, yields value of GoF (Tenenhaus Goodness of Fit) 0.350. The GoF value indicates thatresearch structural model suitable for the overall empirical data obtained (information: 0.25> $\mathrm{GoF} \geq 0.1=$ small; $0.36>\mathrm{GoF} \geq 0.25=$ moderate; $\mathrm{GoF} \geq 0.36=$ large). The Average R-Squared Index (ARS) and Average Path Coefficient (APC) were evaluated based on the $95 \%$ unbiased bootstrap confidence interval, and the results were significant. The results of the GoF, ARS, AFVIF, and APC analyzes mean that the measurement and structural models deserve to be analyzed further (Table 3).
Analysis of the structural model for the sustainability of water resources (Figure 1) using WarpPLS gives the results as shown in Figure 2.

Information: $\square=$ path coefficient; $\mathrm{P}$ value $<0.01$ (strongly significant); $0.05<$ value $\mathrm{P} \leq 0.01$ (significant); $0.1<\mathrm{P}$ value $\leq 0.05$ (weak significance), and ts $=\mathrm{P}$ value $\geq 0.1$ (not significant).

Table 4 presents the results of statistical analysis on the direct and indirect effects between factors, based on path coefficient values, $p$ values, and effect sizes.

Table 3. Quality Index Model

\begin{tabular}{llll}
\hline Quality Index & Number & Criteria & Explanation \\
\hline ARS & $0.275, \mathrm{P}<0.001$ & $\mathrm{P}<0.05$ & Significant \\
AFVIF & 1,739 & Accepted if $\leq 5$, ideal $\leq 3.3$ & Ithe deal \\
APC & $0.293, \mathrm{P}<0.001$ & $\mathrm{P}<0.05$ & Significant \\
\hline
\end{tabular}

Note: $\mathrm{p} \leq 0.001=$ strong significant; $0.001<\mathrm{p} \leq 0.05=$ moderate significant; $0.05<\mathrm{p} \leq 0.1=$ weak significant; $\mathrm{ns}=$ nonsignificant 


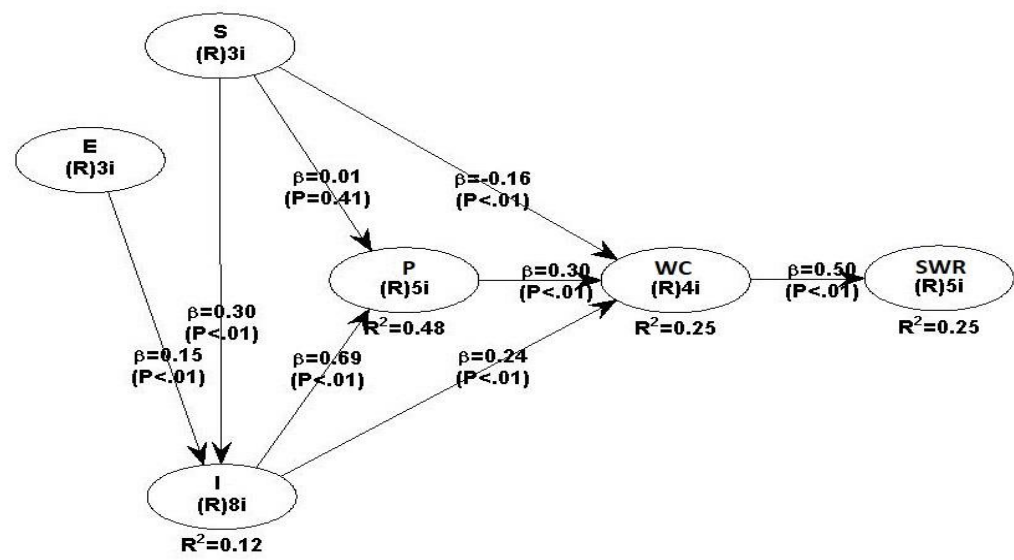

Figure 2 The results of the analysis of the structural model for the sustainability of water resources.

Table 4. Path coefficient value, $P$ value, and Effect sizes.

\begin{tabular}{|c|c|c|c|c|}
\hline Pathway & Coeff path & $P$ value & $\mathrm{f} 2$ & f2 of total effects \\
\hline Social $\square$ Institutional & 0.297 & $<0.001$ & 0.092 & 0.092 \\
\hline Social $\square$ Partnership & 0.014 & 0.407 & 0.003 & 0.045 \\
\hline Social $\square$ Institutional $\square$ Partnership & 0.205 & $<0.001$ & 0.043 & \\
\hline Social $\square$ Water conservation & -0.156 & 0.004 & 0.017 & 0.002 \\
\hline Social $\square$ Institutional $\square$ Water conservation & 0.077 & 0.095 & 0.009 & \\
\hline \multicolumn{5}{|l|}{ Social $\square$ Partnership $\square$ Water conservation } \\
\hline Social $\square$ Institutional $\square$ Partnership $\square$ Water conservation & 0.061 & 0.037 & 0.007 & \\
\hline Social $\square$ Water Conservation $\square$ Sustainability of water & -0.078 & 0.030 & 0.009 & 0.001 \\
\hline $\begin{array}{l}\text { Social } \square \text { Institutional } \square \text { Water conservation } \square \text { Sustainability } \\
\text { of water resources }\end{array}$ & 0.038 & 0.212 & 0.004 & \\
\hline $\begin{array}{l}\text { Social } \square \text { Partnership } \square \text { Water conservation } \square \text { Sustainability } \\
\text { of water resources }\end{array}$ & & & & \\
\hline $\begin{array}{l}\text { Social } \square \text { Institutional } \square \text { Partnership } \square \text { Water } \\
\text { conservation } \square \text { Sustainability of water resources }\end{array}$ & 0.030 & 0.152 & 0.004 & \\
\hline Economy $\square$ Institutional & 0.145 & 0.006 & 0.024 & 0.024 \\
\hline Economy $\square$ Institutional $\square$ Partnership & 0.100 & 0.008 & 0.016 & 0.016 \\
\hline Economy $\square$ Institutional $\square$ Water conservation & 0.035 & 0.197 & 0.006 & 0.011 \\
\hline Economy $\square$ Institutional $\square$ Partnership $\square$ Water & 0.030 & 0.192 & 0.005 & \\
\hline $\begin{array}{l}\text { Economy } \square \text { institutional } \square \text { Water } \\
\text { conservation } \square \text { Sustainability of water resources }\end{array}$ & 0.018 & 0.301 & 0.003 & 0.006 \\
\hline $\begin{array}{l}\text { Economy } \square \text { Institutional } \square \text { Partnership } \square \text { Water } \\
\text { conservation } \square \text { Sustainability of water resources }\end{array}$ & 0.015 & 0.308 & 0.003 & \\
\hline Institutional $\square$ Partnership & 0.689 & $<0.001$ & 0.478 & 0.478 \\
\hline Institutional $\square$ Water conservation & 0.244 & $<0.001$ & 0.103 & 0.189 \\
\hline Institutional $\square$ Partnership $\square$ Water conservation & 0.204 & $<0.001$ & 0.086 & \\
\hline Institutional $\square$ Water conservation $\square$ Sustainability of water & 0.122 & 0.002 & 0.081 & 0.149 \\
\hline $\begin{array}{l}\text { Institutional } \square \text { Partnership } \square \text { Water } \\
\text { conservation } \square \text { Sustainability of water resources }\end{array}$ & 0.102 & 0.001 & 0.068 & \\
\hline Partnership $\square$ Water conservation & 0.296 & $<0.001$ & 0.134 & 0.134 \\
\hline Partnership $\square$ Water conservation $\square$ Sustainability of water & 0.148 & $<0.001$ & 0.083 & 0.083 \\
\hline Water conservation $\square$ Sustainability of water resources & 0.500 & $<0.001$ & 0.250 & \\
\hline
\end{tabular}


Information: $\square=$ path coefficient; $\mathrm{P}$ value $<0.01$ (strongly significant); $0.05<\mathrm{P}$ value $\leq 0.01$ (significant); $0.1<\mathrm{P}$ value $\leq 0.05$ (weakly significant), and ts $=\mathrm{P}$ value $\geq 0.1$ (not significant); small effect $(0.02 \leq \mathrm{f} 2<0.15)$, medium effect $(0.15 \leq \mathrm{f} 2<0.35)$, or large effect $(0.35 \leq \mathrm{f} 2)$.

\subsection{Create a Discussion}

The forest in the upstream area of the Brantas River Basin is a protected area as well as a source of raw water, a source of livelihood for the surrounding community and a power plant. From 2000 to 2018, it is known that there has been a change in the function of forest land and fields in the central and downstream Brantas watershed in the Poncokusumo District area. The conversion of forest land and fields into shrubs, settlements, rice fields and moor; interfere with the absorption, storage and distribution of rainwater. The ability of land in the area to prevent sedimentation and prevent deterioration of water quality has decreased. Several springs in Malang Regency were found to have decreased in quantity and quality [6] [7].

The geographic conditions of the research area support agricultural activities, namely: located at an altitude of 500-1000 masl and the slope is wavy to flat (downstream of the watershed). Empirical data shows that the main occupation of most people is farming $(61.18 \%)$. In Poncokusumo sub-district, farmers are a descending profession, and the community thinks that the level of primary school education is considered sufficient (59.30\%). $87.48 \%$ of the people earn below the Malang Regency Minimum Wage in 2019 (IDR 2,800,000). This indicates that most of the people have not been able to fulfill their welfare needs. The level of viability or welfare can be increased through opportunities for access to information and education / better self-development [6] [8] [9].

Indicators of social research variables are: trust, honesty, and obedience. Honesty (loading factor 0.843 ) is the strongest indicator of social variables. The honesty of every villager is the main basis for community social capital. Trust, honesty, and obedience; is a relational dimension of social capital [10]. The indicators of the research social variables are in a good category, so it is detected that the community in the research area has a good impersonal relationship basis with external parties. The external party in the structural model is the village institution.

Indicators of economic variables are: willingness to contribute, ability to contribute, and cost of water conservation, in either category. Willingness to contribute (loading factor 0.772 ) is the strongest indicator of economic variables, so it is the key to the success of water management in the village from economic factors. The condition of these economic factors is juxtaposed with the income of the people who are below Regional Minimum Wage (UMR). Economic contribution to water conservation efforts is still in the willingness to contribute and can be borne (in terms of monthly income) of the community [11]. Based on the results of the interview, the specific cost for water conservation activities in the village has not been determined. Water conservation activities are included in village environmental management activities, which do not require special and designed costs.

Village institution variable indicators are: duties and responsibilities, PSDM, planning, administration, guidance, information center, compliance, and enforcement of regulations. Administration and compliance are indicators of social variables in either category. Village institution staff come from the local village community, which means that village social capital also influences the character of the village institution. Honesty is reflected in good and transparent administration by village institution staff. Compliance is an expression of the trust and adherence of agency staff to policies and regulations established by local, regional, and national governments. Meanwhile the indicators: duties and responsibilities, PSDM, planning, guidance, information center, and law enforcement are still in the poor category. The 6 (six) indicators relate to the professional ability of village program management as an institution. The most important institutional indicator is the PSDM (loading factor 0.783). The statement in the PSDM indicator relates to the opportunity for village institution staff to participate in self-development activities related to the objectives of institutional water resource sustainability program management [11] [12]. Empirical data states that village agency staff have participated in water management activities once or twice, so they are in the poor category. It is still necessary to adjust the professionalism of village institutions in water management through PSDM. The statement in the PSDM indicator relates to the opportunity for village institution staff to participate in self-development activities related to the objectives of institutional water resource sustainability program management [11] [12]. Empirical data states that village agency staff have participated in water management activities once or twice, so they are in the poor category. It is still necessary to adjust the professionalism of village institutions in water management through PSDM. The statement in the PSDM indicator relates to the opportunity for village institution staff to participate in self-development activities related to the objectives of institutional water resource sustainability program management [11] [12]. Empirical data states that village agency staff have participated in water management activities once or twice, so they are in the poor category. It is still necessary to adjust the professionalism of village institutions in water management through PSDM.

The indicator of the partnership variable in the good category is the ease of obtaining information, related to information / administration openness, while the other 
indicators are in the poor category. Village institutions are not yet good at partnering: training and guiding, inviting participation, assisting in utilizing water, and managing the application of water source conservation; with the villagers. Training and mentoring (loading factor 0.647 ) have a poor category and is the strongest indicator of the partnership variable. The partnership between village institutions and residents in conducting water conservation can be strategically enhanced through increasing the effectiveness of training and assistance in water conservation for villagers. Community knowledge and skills about the importance and how to carry out water conservation,

Water conservation variable indicators consist of: government regulations, local regulations, land, and environmental sanitation. Local regulation (loading factor 0.737 ) is in the poor category and is the strongest indicator of water conservation variables. Local regulations are derivatives of government regulations whose practical implementation is adjusted to village conditions and capacities and set by the Village Head. Local regulations regarding the implementation of water conservation in the watershed from upstream to downstream have not been well described and implemented. The logic of this condition is that the village has not complied with government regulations on water resources management (information: including land use regulations). Hence the accuracy and enforcement of local regulations,

Water resources in this research are water sources that are potential to be used for daily needs, economic activities, and public services. Sustainability of water resources is the sustainability of water sources that benefits the village. Water resources sustainability indicators are: water quantity, water quality, reforestation, health and improved services. The quality of water used by the community is in good category. The water sources used are springs and rivers, which are still not polluted. Meanwhile, for the quantity of water, afforestation, environmental health, and improved services; in the category yet good. Greening (loading factor 0.701) and environmental health (loading factor 0.702 ) are the strongest indicators for the sustainability of water resources. The watershed from upstream to downstream must maintain the function of recharge, infiltration, and water distribution, by ensuring the suitability of land vegetation density. This assurance is the result of the effectiveness of implementing the reforestation program. The quantity and continuity of water discharge from sources is guaranteed with an appropriate reforestation program. Meanwhile, environmental sanitation in water conservation activities is closely related to the environmental health of water sources. The water source will continue as a water resource for the village, if the quality of the water used is not polluted or according to its purpose. This study resulted in the finding that the sustainability of water resources is supported primarily through strengthening the quality of reforestation programs and environmental health of water sources [13]. This assurance is the result of the effectiveness of implementing the reforestation program. The quantity and continuity of water discharge from sources is guaranteed with an appropriate reforestation program. Meanwhile, environmental sanitation in water conservation activities is closely related to the environmental health of water sources. The water source will continue as a water resource for the village, if the quality of the water used is not polluted or according to its purpose. This study resulted in the findings that the sustainability of water resources is supported primarily through strengthening the quality of reforestation programs and environmental health of water sources [13]. This assurance is the result of the effectiveness of implementing the reforestation program. The quantity and continuity of water discharge from sources is guaranteed with the right reforestation program. Meanwhile, environmental sanitation in water conservation activities is closely related to the environmental health of water sources. The water source will continue as a water resource for the village, if the quality of the water used is not polluted or according to its purpose. This study resulted in the finding that the sustainability of water resources is supported mainly through strengthening the quality of reforestation programs and environmental health of water sources [13]. Meanwhile, environmental sanitation in water conservation activities is closely related to the environmental health of water sources. The water source will continue as a water resource for the village, if the quality of the water used is not polluted or according to its purpose. This study resulted in the finding that the sustainability of water resources is supported primarily through strengthening the quality of reforestation programs and environmental health of water sources [13]. Meanwhile, environmental sanitation in water conservation activities is closely related to the environmental health of water sources. The water source will continue as a water resource for the village, if the quality of the water used is not polluted or according to its purpose. This study resulted in the finding that the sustainability of water resources is supported primarily through strengthening the quality of reforestation programs and environmental health of water sources [13].

The community has honesty in utilizing water and obeying village to national regulations related to water conservation. There is a sense of trust among villagers that other residents also apply the same thing regarding the use and conservation of water in their village. Village communities as a collection of individuals, with such social capital, are involved and empowered by village institutions to carry out water conservation. Good impersonal relationships village institutions have a direct effect on the quality of the performance of village 
institutions $(\square=0.297, \mathrm{P}<0.001$, f2 $=0.092)$. The economic contribution (indicator: willingness to contribute, ability to pay, and activity costs) of the village community also directly affects the performance and institutional programs $(\square=0.145, \mathrm{P}<0.006, \mathrm{f} 2=0.024)$.

The results of the analysis of the research structural model (Table 3), found that the direct influence of the social factors of the village community on the partnership, has a small effect (f2 =0.003), so it is ignored in the next study. Partnership in this research is about sharing perceptions and synergies between village institutions / institutions and village communities. The effect of social factors in rural communities on partnerships for water conservation is greater through the mediation of institutional factors $(\square=0.205$, P $<0.001$, f2 $=0.045)$. Good village institutional performance and strong social capital support positive community-village institutional partnerships. A different thing is the economic influence of rural communities, through institutional mediation, which does not have a sufficient effect on partnerships ( $f 2=0.016$ ). Community economy affects the planning and operation of institutional programs [11] [12].

Institutions have a greater direct influence on partnerships ( $\square=0.689, \mathrm{P}<0.001, \mathrm{f} 2=0.478$ ) compared to water conservation $(\square=0.244, \mathrm{P}<0.001, \mathrm{f} 2=0.103)$. Therefore, partnerships are an important channel for institutions to influence the implementation of water conservation in villages $(\square=0.204, \mathrm{P}<0.001$, f2 $=$ 0.806). The implementation and success of water conservation in rural areas is more secure if there is a partnership or synergy between community-village institutions. Furthermore, water conservation becomes a mediator for the effect of partnerships on the sustainability of water resources $(\square=0.148, \mathrm{P}<0.001$, f2 $=0.083$ ).

Referring to the analysis results as contained in Table 3 , the sustainability of water resources is mainly influenced directly by the water conservation variable (f2 $=0.250$ ) and subsequently by the institutional variable (f2 $=0.149)$. Meanwhile, the water conservation variable is influenced by institutional variables ( $\mathrm{f} 2=0.189$ ) and partnership (f2 $=0.134)$. Partnership variables are influenced by institutional variables ( $\mathrm{f} 2=0.478$ ) and these institutional variables are more influenced by social variables ( $\mathrm{f} 2=0.092$ ) than by economic variables (f2 $=$ 0.024).

Based on the effect sizes, the intervention recommendations for village governments are as follows. Program quality and institutional performance are supported by the economic contribution of the community, by ensuring the willingness of the community to contribute economically. Village institutions with good and open administration and obeying regulations and policies, assuring the community that village institutions can be trusted.
Strengthening the social capital (trust, honesty and obedience) of the village community must be done through improving the performance of village institutions. The most strategic improvement in the performance of village institutions is done through the effectiveness of the PSDM of village institution staff. Improving staff capacity, improving the quality and effectiveness of institutional products (local regulations) and impersonal relations between village communities and institutions. Good impersonal relationship, strengthen the social capital capacity of village communities in community-village institution partnerships for the implementation of water conservation. Training and mentoring, in the partnership process, must continue to ensure the effectiveness of the output (water conservation) of the partnership. The analysis shows that local (village) regulations on water conservation are a key criterion to ensure that the sustainability of water resources can be achieved. Local (village) regulations regarding water conservation by villages are derived from national regulations and then adapted to village conditions and capacity to implement. Again, it must be ensured that the staff of village institutions, through institutional capacity building (PSDM), are able to formulate appropriate local (village) regulations regarding water conservation. continue to be done to ensure the effectiveness of the output (water conservation) of the partnership. The results of the analysis show that local (village) regulations on water conservation are a key criterion to ensure that the sustainability of water resources can be achieved. Local (village) regulations regarding water conservation by villages are derived from national regulations and then adapted to village conditions and capacity to implement. Again, it must be ensured that the staff of village institutions, through institutional capacity building (PSDM), are able to formulate appropriate local (village) regulations regarding water conservation. continue to be done to ensure the effectiveness of the output (water conservation) of the partnership. The analysis shows that local (village) regulations on water conservation are a key criterion to ensure that the sustainability of water resources can be achieved. Local (village) regulations regarding water conservation by villages are derived from national regulations and then adapted to village conditions and capacity to implement. Again, it must be ensured that the staff of village institutions, through institutional capacity building (PSDM), are able to formulate appropriate local (village) regulations regarding water conservation. is a key criterion to ensure that the sustainability of water resources can be achieved. Local (village) regulations regarding water conservation by villages are derived from national regulations and then adapted to village conditions and capacity to implement. Again, it must be ensured that the staff of village institutions, through institutional capacity building (PSDM), are able to formulate appropriate local (village) regulations regarding water conservation. is a key 
criterion to ensure that the sustainability of water resources can be achieved. Local (village) regulations regarding water conservation by villages are derived from national regulations and then adapted to village conditions and capacity to implement. Again, it must be ensured that the staff of village institutions, through institutional capacity building (PSDM), are able to formulate appropriate local (village) regulations regarding water conservation.

\section{CONCLUSION}

Community social capital in the form of strong impersonal relationships with village institutions $(\square=$ $0.297, \mathrm{P}<0.001, \mathrm{f} 2=0.092$ ) is the starting point of intervention for the government to ensure that the community-village synergy (partnership) in conducting water conservation is effective for the realization of the sustainability of water resources. In this study, the model of community-based water resource sustainability and village institutions can be used as a reference to predict the facts and potential interventions carried out by the village government. For a wider area, further research should include elements of local government and central government in the partnership and water conservation factors.

\section{ACKNOWLEDGMENTS}

Thank you to the community and village institutions for providing data and information openly during the research. Thanks to reviewers and proofreaders, who helped improve the quality of this scientific article.

\section{REFERENCES}

[1] Nana, Dede, 2019. "Making Anxiety, 60 Malang Regency Springs Shrink". In Jatim Times. https://jatimtimes.com/baca/189639/20190314/200 700/bikin-cemas-60-sumber-mata-air-kabupatenmalang-menyusut [11/14/2020]

[2] Fizriyani, Wilda, 2019. "The Springs In Malang Are Getting Smaller”. In Republika.co.id. https://nasional.republika.co.id/berita/q0y3nn430/s umber-mata-air-di-malang-semakin-menyusut [11/14/2020]

[3] Massiri, Sudirman, Nugroho, Bramasto, and Kartodiharjo, Hariadi, 2019. "Institutional Sustainability of A Community Conservation Agreement in Lore Lindu National Park". In Forest and society, 3(1). E Journal on-line. https://www.researchgate.net/publication/3327678 90_Institutional_Sustainability_of_a_Community_ Conservation_Agreement_in_Lore_Lindu_Nationa 1_Park [11/10/2020].
[4] Sudarmadji, Sudarmadji, Sugiarto, Fajar, Sari, Ratna Destra Kurnia, Riyanto, Indra Agus, Cahyadi, Ahmad, dan Sudrajat, 2017. "Tradisi Dan Religi Sebagai Upaya Konservasi Mata Air Masyarakat Perdesaan: Studi Kasus Masyarakat Kecamatan Girimulyo, Kabupaten Kulon Progo (Tradition and religion as means of the rural community in spring conservation: a case study of Girimulyo Distric, Kulon Progo Region)". In Jurnal Penelitian Pengelolaan Daerah Aliran Sungai (Journal of Watershed Management Research), 1(1). E Journal on-line. http://ejournal.forda-mof.org/ejournallitbang/index.php/JPPDAS/article/view/2108 [11/12/2020].

[5] Kock, Ned, 2015. WarpPLS 5.0 User Manual. ScriptWarp Systems. Laredo, Texas. http://cits.tamiu.edu/WarpPLS/UserManual_v_5_0. pdf $[11 / 5 / 2020]$.

[6] Nurfatriani, Fitri dan Muttaqin, Zahrul, 2009. "The Economic Value Of Water For Commercial Use In Upper Brantas Sub-Watershed". Dalam Journal of Forestry Research, 5(2):75-89. E Journal on-line. Melalui http://ejournal.forda-mof.org/ejournallitbang/index.php/IJFR/article/view/150 [11/12/2020].

[7] Sulistyaningsih, Tri, Sulardi, dan Sunarto, 2013. Model Collaboration Partnership Management of Watershed Green Open Space for the Sustainability of National Strategic Rivers. National Strategy Annual Report, Malang.

[8] Cronin, Aidan A., Odagiri, Mitsunori, Arsyad, Bheta, Nuryetty, Mariet Tetty, Amanullah, Gantjang, Santoso, Hari, Darundiyah, Kristin, and Nasution, Nur Aisyah, 2017. "Piloting Water Quality Testing Coupled With A National Socioeconomic Survey In Yogyakarta Province, Indonesia, Towards Tracking Of Sustainable Development Goal 6". In International Journal of Hygiene and Environmental Health, no number;111. E Journal on-line. https://www.ncbi.nlm.nih.gov/pubmed/28743592 [11/8/2020].

[9] Willy, Daniel Kyalo, and Holm-Müller, Karin, 2013. "Social Influence and Collective Action Effects On Farm Level Soil Conservation Effort In Rural Kenya”. In Ecological Economics 90:94-103. E Journal on-line. Melalui https://www.sciencedirect.com/science/article/pii/S 0921800913000992 [11/8/2020].

[10] Corry, Dagmar Anna Susanne dan Leacye, Gerard, 2015. "Adolescent Trust and Primary Care: HelpSeeking For Emotional And Psychological Difficulties". In Journal of Adolescence, 54. 
E Journal

on-line.

https://www.researchgate.net/publication/3098484

31_Adolescent_trust_and_primary_care_Helpseeking for_emotional_and_psychological_difficul ties $[11 / 8 / 2020]$.

[11] Darmiatun, Suryatri, Riniwati, Harsuko, Hakim, Luchman, and Suyadi, 2020. "Provision of Drinking Water By Rural Community Groups: Appropriate Models For Sustainability". In TRKU Journal, 62(4).

https://www.kansaiuniversityreports.com/article/pr ovision-of-drinking-water-by-rural-communitygroups-appropriate-models-for-sustainability [11/14/2020].
[12] Darmiatun, Suryatri, Riniwati, Harsuko, Hakim, Luchman, and Suyadi, 2019. "Model for Improving Rural Community Capacity for Sustainability of Water Supply in Poncokusumo, Malang, East Java, Indonesia". Mimeo, paper presented in The International Interdisciplinary Studies Seminar (IISS), Malang, 30-31 October 2019. https://eudl.eu/doi/10.4108/eai.23-102019.2293040 [11/14/2020].

[13] de Boer, Cheryl and Bressers, Hans, (2013),"Water resource co-management and sustainable regional development". In Management Research Review, 36(12): 1238 - 1251. E Journal on-line. Melalui https://journal.unesa.ac.id/index.php/jsm/index [11/16/2020] 